\title{
New Approaches in Targeted Therapy for Medulloblastoma in Children
}

\author{
HENRIETTA MAIER, TINA DALIANIS and OURANIA N. KOSTOPOULOU \\ Department of Oncology-Pathology, Karolinska Institutet, Stockholm, Sweden
}

\begin{abstract}
Medulloblastoma (MB) is the most frequent malignant brain tumor in children. Treatment of $M B$ is based on histopathological and molecular stratification, and includes surgical intervention, often with craniospinal irradiation and adjuvant chemotherapy. Unfortunately, however, this treatment leads to a high morbidity rate, and it does not cure all patients either, with around 30\% succumbing to their disease. With improved cancer genomics and better molecular characterization, $M B$ has been classified into four major subgroups, wingless-activated, sonic hedgehog-activated, Group 3, and Group 4, with each group consisting of additional subtypes. Recently disclosed genetic drivers of $M B$ may in the future help improve treatment, and in this way reduce therapy-related toxicity. In this review, we describe the heterogeneity of the $M B$ subgroups, and potential new options for targeted therapy.
\end{abstract}

Medulloblastoma (MB), the most frequently occurring malignant brain tumor in children, is treated depending on histopathological and molecular stratification, and age, with the current standard of care often including surgery, craniospinal irradiation (CSI) and adjuvant chemotherapy (1). This leads to considerable morbidity among the $70 \%$ of patients that are cured, and leaves the remaining 30\% in need of better therapeutic options since they are not cured (1-3). With advanced cancer genomics, elucidation of the molecular

This article is freely accessible online.

Correspondence to: Ourania Kostopoulou Ph.D., and Tina Dalianis, Prof. MD, PhD, Department of Oncology-Pathology, Karolinska Institutet, Bioclinicum J6:20, Karolinska University Hospital, 171 64 Stockholm, Sweden. Tel.: +46 85172764, e-mail: ourania.kostopoulou@ki.se; tina.dalianis@ki.se

Key Words: Medulloblastoma, wingless-activated subgroup, sonic hedgehog-activated subgroup, Group 3, Group 4, targeted therapy, immunotherapy, review. complexity of $\mathrm{MB}$ has resulted in its classification into four major subgroups, wingless-activated (WNT), sonic hedgehogactivated (SHH), Group 3, and Group $4 \mathrm{MB}$, with each comprising additional subtypes (2). Genomic data have also identified genetic drivers for $\mathrm{MB}$, and, as specific targets, these could potentially help improve present treatment options considerably and thereby reduce therapy-related toxicity (3).

In this review, we describe the heterogeneity of the MB subgroups, and some advances in targeted therapy. We also focus on pathways that drive MB tumorigenesis, and present an overview of some current preclinical and clinical studies targeting the hedgehog $(\mathrm{HH})$, phosphoinositide 3-kinase (PI3K), cyclin-dependent kinase 4 and 6 (CDK4/6) pathways, as well as approaches in immunotherapy. While research continuously sheds more light on the individual genomic complexity of $\mathrm{MB}$, the challenge lies in the comprehensive evaluation and translation of newly obtained data into new therapeutic approaches.

\section{Epidemiology and Symptomatology}

Brain tumors are the most frequent solid tumors in children, and among these, MB represents the most common malignant one, accounting for $20 \%$ of all pediatric brain tumors $(1,4)$. The incidence of $\mathrm{MB}$ in children is roughly five cases per million individuals, and in adults, around one case per 2 million individuals $(4,5)$. MB is mainly observed the first 9 years of life, with a peak incidence between 4 to 7 years of age (6). Although the sex predominance differs between MB subtypes, males are generally 1.5-2 times more frequently affected than females (4).

The World Health Organization has classified MB as a grade IV tumor, usually originating in the cerebellum or the posterior fossa, and shown to spread via the cerebrospinal fluid to the brain and spine $(2,7)$. In children, MB is mostly located in the midline of the cerebellum, whereas in adults, lateral tumors are more frequent (7). Histologically, the tumor consists of densely packed cells, which are predominantly undifferentiated. If 
differentiation occurs, cells differentiate mostly into neuronal cells, or less commonly, into glial cells (2).

Individual symptoms of $\mathrm{MB}, e . g$. headache, clumsiness, nausea, morning vomiting, fatigue, as well as poor school performance, or other nonspecific features, depend mainly on tumor location but can also be due to increased intracranial pressure, or to direct effects of the tumor mass (8). In addition, ataxia, difficulties with handwriting, vision, or other motor skills can result from MB (8). Due to the rapid development of $\mathrm{MB}$, presentation of symptoms is frequently observed in fewer than 3 months after the tumor has developed (9). The median period of time until diagnosis from the first symptoms is around 2 months. An early diagnosis can positively affect the patient's outcome, since metastases are observed in $30 \%$ of all patients at diagnosis $(8,10)$. Neuroimaging, such as non-contrast computed tomography of the head is performed as a first line of diagnostics (11). This is followed by confirmatory magnetic resonance imaging with and without gadolinium, and provides further information about the relationship between the tumor and the surrounding brain structures and also identifies whether metastases are present (11). Notably, the molecular subgroup can often be determined by the location of the tumor, since WNT tumors mainly occur in the cerebellar peduncle or cerebellopontine angle, while $\mathrm{SHH}$ MB is preferably located in the cerebellar hemisphere (12). In contrast, Group 3 and Group $4 \mathrm{MB}$ are usually found in the midline (12). Ultimately, however, histopathological and molecular information is required for correct subgroup determination and a more detailed description of the different molecular subgroups of MB is presented below.

\section{Molecular Subgroups of Medulloblastoma, Risk Stratification, and Quality of Life}

MB is usually divided into four molecular subgroups, named according to the specifically altered cellular pathway or the specific genomic variations they harbor: WNT, SHH, Group 3 and Group 4 MB (Table I). Within each subgroup, there are further subdivisions (10).

Wingless-activated $M B$. This subgroup accounts for approximately $10 \%$ of all MB cases, and is most common between ages 6-10 years or later, and is relatively equally distributed between males and females; with a $90 \%$ 5-year survival rate, it has a very good prognosis compared to other MB subgroups $(8,13)$. In $80-90 \%$ of cases, WNT MB presents somatic activating mutations in exon 3 of CTTNB1, which encodes $\beta$-catenin, and these mutations stabilize this protein, and in $85-90 \%$ of these same cases, a partial loss of chromosome 6 is observed $(1,8)$. Stabilized $\beta$-catenin accumulates in the nucleus and co-activates transcription factors, which enhance the expression of WNT-responsive genes, which in turn up-regulate cell growth and proliferation $(8,14)$. In patients, without CTTNB1 mutations, mutations of the tumor suppressor adenomatous polyposis coli $(A P C)$ gene are frequent $(1,8,15)$. APC normally is able to build a complex with axin 1 , axin 2 , casein kinase 1 alpha 1 and glycogen synthase kinase 3 beta to drive ubiquitylation and degradation of $\beta$-catenin. Loss-of-function mutations of $A P C$, with more active $\beta$-catenin, can therefore also constitutively activate WNT signaling. By increasing the understanding of the molecular background of WNT MB, targeted therapies might be helpful in reducing the amounts of chemotherapy agents required. However, targeting the $\mathrm{WNT} / \beta$-catenin pathway directly would be critical, since it plays an important role during embryonal development, regulating stem cell pluripotency and driving cell growth and proliferation $(3,8)$. However, since WNT signaling is also required for bone formation, inhibition of WNT can lead to osteoporosis (3).

Sonic hedgehog-activated MB. This accounts for 25-30\% of all MB and mainly affects infants (younger than 3 years) and adults, and in the latter, it is the predominant group (60\%), while it generally spares children above 3 years old (1). Patients with SHH MB have an overall survival of about $70 \%$, however, outcome strongly depends on additional molecular events, e.g. TP53 status $(1,16)$. SHH MB is driven by germline or somatic mutations and copy-number variations in genes of the SHH pathway, such as loss-offunction mutations or deletions of protein patched homolog 1 (PTCHI) (43\% of all patients) or SUFU negative regulator of hedgehog signaling ( $S U F U$ ), activating mutations in smoothened (SMO), or amplifications of zinc finger protein GLI1/2 (GLII/GLI2) or MYCN proto-oncogene (MYCN) (1, 17). These molecular alterations result in a constitutive, ligand-independent activated $\mathrm{SHH}$ signaling. Normally, $\mathrm{SHH}$ binds PTCH1 leading to a release of SMO, which is responsible for the dissociation of the transcription factor GLI from SUFU (17). Subsequently, unbound GLI is translocated to the nucleus and activates the expression of SHH-activated genes, which drive cellular differentiation, organ formation and post-embryonic tissue regeneration (8, 18). SMO presents a favorable candidate for targeted therapies, but since it has an essential role during development, SMO antagonists can lead to serious growth plate challenges in younger patients $(8,19)$. Another important characteristic of SHH MB is its TP53 status, since patients harboring TP53 mutations have a 5-year survival rate of around $40 \%$, while those with wild-type TP53 SHH MB have an increased survival rate of approximately $80 \%$ (1). Interestingly, TP53 is also commonly mutated in WNT MB but does not affect overall survival (20). Copy-number variations of TP53 or the receptor tyrosine kinase $P I 3 K$ are also commonly observed in SHH MB tumors (1). TP53 has 
Table I. Overview of the four subgroups of medulloblastoma. Wingless (WNT)-activated, sonic hedgehog (SHH)-activated, Group 3 and Group 4 medulloblastoma $(\mathrm{MB})$ are compared regarding clinical, molecular and pathological characteristics [adapted from Szalontay and Khakoo (11)].

\begin{tabular}{|c|c|c|c|c|c|}
\hline & & \multicolumn{4}{|c|}{ MB subgroup } \\
\hline & & WNT & SHH & Group 3 & Group 4 \\
\hline Clinical data & $\begin{array}{l}\text { Age group } \\
\text { Gender distribution } \\
\text { Prognosis } \\
\text { 5-Year survival } \\
\text { Metastasis }\end{array}$ & $\begin{array}{c}\text { Children and adults } \\
\text { Equal } \\
\text { Very good } \\
97-100 \% \\
8.6-21-4 \%\end{array}$ & $\begin{array}{c}\text { Infants and adults } \\
\text { Equal } \\
\text { Good } \\
67.3-88.5 \% \\
8.9-20 \%\end{array}$ & $\begin{array}{c}\text { Infants and children } \\
\text { Male predominance } \\
\text { Poor } \\
41.9-66.2 \% \\
20-43.3 \%\end{array}$ & $\begin{array}{c}\text { Children and adults } \\
\text { Male predominance } \\
\text { Intermediate } \\
66.8-82.5 \% \\
38.7-40.7 \%\end{array}$ \\
\hline Occurrence & $10 \%$ & $30 \%$ & $25 \%$ & $35 \%$ & \\
\hline Mutation & & $C T N N B 1, A P C$ & $\begin{array}{l}\text { PTCH1, SUFU, } \\
\text { SMO, TP53 }\end{array}$ & GFII & $\begin{array}{l}\text { KDM6A, ZMYM3, } \\
\text { KMT2C, KBTBD4 }\end{array}$ \\
\hline \multicolumn{2}{|c|}{ Copy-number alterations } & Monosomy of chr6 & $\begin{array}{c}M Y C N \text { amplification } \\
\text { GLI2 amplification } \\
\text { Copy-number variations } \\
\text { of } T P 53 \text { or } P I 3 K\end{array}$ & $\begin{array}{c}\text { OTX2 gain } \\
\text { MYC amplification } \\
\text { Isochromosome } 17 \mathrm{q}\end{array}$ & $\begin{array}{c}\text { Isochromosome } 17 \mathrm{q} \\
\text { Gain of chromosome } \\
717 \mathrm{q} \\
\text { Deletion of } \\
\text { chromosome } \\
8,11,18 \mathrm{p}\end{array}$ \\
\hline Tumor locatior & & $\begin{array}{l}\text { Cerebellar penduncle/ } \\
\text { cerebellopontine angle }\end{array}$ & $\begin{array}{l}\text { Cerebellar } \\
\text { hemisphere }\end{array}$ & $\begin{array}{l}\text { Midline, ill-defined } \\
\text { margins }\end{array}$ & $\begin{array}{l}\text { Midline, no } \\
\text { enhancement }\end{array}$ \\
\hline Origin & & $\begin{array}{l}\text { Cells in the lower } \\
\text { rhombic lip }\end{array}$ & $\begin{array}{l}\text { Cerebellar granule } \\
\text { neuron progenitors }\end{array}$ & Uncertain & Uncertain \\
\hline Histology & & Classic & $\begin{array}{l}\text { Desmoplastic nodular } \\
\text { (MBEN - infant, LC/A } \\
\text { - TP53-mutant) }\end{array}$ & $\begin{array}{c}\text { Classic } \\
(\mathrm{LC} / \mathrm{A}-\text { infant })\end{array}$ & Classic \\
\hline
\end{tabular}

APC: Adenomatosis polyposis coli; chr6: chromosome 6; CTNNB1: catenin beta 1; GFI1: growth factor independent 1 transcriptional repressor oncoprotein; GLI2: GLI family zinc finger 2; KBTBD4: kelch repeat and BTB domain containing 4; KDM6A: lysine demethylase 6A; KMT2C: lysine methyltransferase 2C; LC/A: large cell/anaplastic; MBEN: medulloblastoma with extensive nodularity; MYC: MYC proto-oncogene; MYCN: MYCN proto-oncogene; OTX2: orthodenticle homeobox 2; PI3K: phosphoinositide 3-kinase; PTCH1: patched homolog 1; SMO: smoothened; SUFU: SUFU negative regulator of hedgehog signaling; TP53: tumor protein p53; ZMYM3: zinc finger MYM-type containing 3.

a checkpoint role for DNA damage and repair, therefore its dysregulation results in defective apoptosis, whereas the PI3K pathway drives proliferation and cellular growth (21). Based on DNA methylation data, four subclasses ( $\mathrm{SHH} \alpha$, $\mathrm{SHH} \beta, \mathrm{SHH} \gamma$ and SHHס) represent clinically relevant distinct subgroups (22).

Group $3 \mathrm{MB}$. This subgroup comprises $25 \%$ of all MB cases, and mainly affects children 2-5 years of age, with male predominance; it is associated with the worst prognosis $(50 \%$ overall survival rate) (1). Group $3 \mathrm{MBs}$ are primarily characterized by a high-level of $M Y C$ loci amplification but other molecular features, such as presence of isochromosome $17 \mathrm{q}$, loss or gain of chromosome 8q (MYC locus at 8q24), and activation of the growth factor independent 1 transcriptional repressor oncoprotein (GFII), and orthodenticle homeobox
(OTX) amplification are also described (22). Group $3 \mathrm{MB}$ relapses mainly in form of metastases, which are rarely observed in the same location as the primary tumor (23). Due to its dismal prognosis, targeted therapies are of high interest for this subgroup.

Group $4 \mathrm{MB}$. Accounting for $35 \%$ of all MB cases, Group 4 $\mathrm{MB}$ is more common in males, and while its general prognosis is good, patients with an initially metastatic disease have a much higher risk of relapse $(3,24)$. No consensus mutation has been identified as most frequent in this MB subgroup but genetic alterations which drive Group $4 \mathrm{MB}$ include mainly the overexpression of the histone-modifying PR/SET domain protein (PRDM6), and mutations in other genes such as lysine demethylase 6A (KDM6A), zinc finger, MYM-type containing 3 (ZMYM3), lysine methyltransferase 
2C (KMT2C) and kelch repeat and BTB domain containing 4 (KBTBD4) have also been described (15). In addition, this group is associated with a high burden of chromosomal copynumber variations, with gain of chromosome 7 or $17 \mathrm{q}$, deletion of chromosome 8,11 or $18 \mathrm{p}$, and isochromosome $17 q(11)$.

Risk stratification. When a patient is considered as having a high risk for poor outcome, factors such as age, extent of resection, metastasis and histological subtype play an important role. Average-risk patients are considered to be older than 3 years of age and have a tumor size $<1.5 \mathrm{~cm}^{2}$ after surgery. High-risk group patients have $>1.5 \mathrm{~cm}^{2}$ of tumor after resection and large-cell anaplastic histology (11). However, rather than classifying risk by clinicopathological variables, today risk stratification on a molecular subtypebased approach is recommended (25).

Thereby the low-risk group, with a survival higher than $90 \%$, includes patients younger than 16 years of age with non-metastatic WNT MB, or non-metastatic Group $4 \mathrm{MB}$ with genetic events as loss of chromosome 11 or gain of chromosome 17 (25). The standard-risk group (survival of 75-90\%) comprises patients with non-metastatic SHH MB with tumors without a TP53 mutation or $M Y C N$ amplification, and those with non-metastatic and non- $M Y C$ amplified Group 3 MB (25). Patients with metastatic noninfant, TP53 wild-type and MYCN-amplified non-metastatic SHH MB and metastatic Group $4 \mathrm{MB}$ are considered as high-risk (survival 50-75\%) (25). The very high-risk group has a survival rate of less than $50 \%$, and includes patients with SHH MB harboring TP53 mutations, or Group $3 \mathrm{MB}$ with metastasis (25).

Quality of life. The tumor, as well as its treatment, affects brain development. As a consequence, neurological, neuropsychological and physical disabilities occur in adult survivors of childhood MB (26, 27). Therapeutic interventions such as surgery, alone or together with chemotherapy, and CSI can lead to reduced intelligence, deficits in speed of processing, attention, memory and executive functions. Tumors located in the cerebellum impair motor and behavioral functions (8). Survivors of SHH MB generally have a higher quality of life and intelligence compared to those of other subgroups (28). Of note, $95 \%$ of MB-associated deaths are not due to the primary tumor but to recurrent and refractory MB (6).

\section{Standard-of-Care Therapies}

Current strategies. Standard treatment for childhood MB consists of surgery, radiation and chemotherapy. The molecular and clinical risk features of each patient should be assessed to provide a maximally curative and minimally harmful treatment (8). After successful surgery, radiation, and adjuvant chemotherapy, patients with WNT MB have an excellent 5-year progression free survival of $>95 \%$, while those with SHH MB and Group $4 \mathrm{MB}$ have an intermediate rate of $70-80 \%$, as compared to only $50-60 \%$ for those with Group 3 MB (25). Nevertheless, many MB survivors suffer from severe neurocognitive, neuro-endocrine and psychosocial deficits due to standard-of-care therapy (8). There is therefore a strong motivation to identify targeted therapies that are less toxic and more effective, in order to reduce the resulting long-term side-effects.

Surgery. After initial MB diagnosis, gross total resection of the tumor is carried out as a first-line of treatment. The volume of the tumor should be reduced as much as possible, while minimizing the risk of post-operative neurological damage (9). The location of the tumor and its relationship with surrounding structures is highly critical, as neurosurgical procedures carry the risk of developing a cerebellar mutism syndrome (CMS) (11). The incidence of CMS strongly varies within the four subgroups of MB but seems to be independent of tumor volume and location (29). Post-operatively, about $25 \%$ of all patients with MB develop difficulties with executive function, linguistic processing, visual spatial abilities and affective modulation, for which risk factors are young age, large tumor volume or midline tumor location (30). Patients with severe CMS are more likely to suffer from long-term neurocognitive effects (29).

Radiation. For children older than the age of 3 years, postoperative radiation is performed as standard of care. Average-risk patients may receive e.g. 23.4 Gy CSI and a higher boost of $55.8 \mathrm{~Gy}$ to the tumor bed, usually combined with weekly doses of cytostatic drugs as radiosensitizer 30 days after surgery, while those classified as high-risk patients are treated with e.g. $36 \mathrm{~Gy}$ CSI and additional boosts to metastases $(31,32)$. Notably, however, pediatric MB survivors commonly suffer from a lower intelligence quotient, memory and defective executive functions (31). Proton-beam radiation presents an alternative to photonbased approaches, since it seems to significantly improve acute toxicities and neurocognitive late effects (33). However, alopecia and radiation necrosis are more common with proton radiation (34).

Chemotherapy. When chemotherapy was added to the standard-of-care therapy as an adjunct to surgery and radiation in 1979, it substantially improved progression-free survival and overall survival rates in patients with and without metastatic MB, even with reduction of the CSI dose (35). Cytostatic drugs need to pass the blood-brain barrier, and today, common chemotherapeutic agents are cisplatin, vincristine, cyclophosphamide and lomustine (10). Multi- 
agent combinations of these drugs in multiple cycles (mostly 4-9 cycles) have been implemented, where a higher cumulative dose is applied for high-risk patients (8). The event-free survival of patients with MB treated with combinations of cisplatin, lomustine and vincristine or a combination of cisplatin, cyclophosphamide and vincristine were reported to be around $81 \%$ or $86 \%$, respectively (35). Since there is a high risk of developing long-term cognitive difficulties from radiation, children under the age of 4 years are in general spared CSI, instead receiving more intense chemotherapy (10).

\section{Targeted Therapies}

General introduction. From a molecular and clinical perspective, $\mathrm{MB}$ is a heterogeneous disease classified into four major subgroups, with distinct genetic profiles, and treated accordingly (36). Current standard therapy, mainly composed of maximal surgical resection followed by CSI and chemotherapy, presents severe treatment-related toxicity, and secondary tumors may also occur $(36,37)$. Reducing these consequences without affecting treatment efficacy is the focus of targeted therapy, aiming to reduce the doses of cytotoxic agents and radiation, as well as optimizing overall survival (38). Tailored therapy for each MB subgroup and subtype is still at its infancy (37). In WNT and SHH MB, some driver mutations and inhibitors interfering in aberrant signaling pathways or targeting somatic mutations have been identified, and are intensively studied in vitro and in vivo. Group $4 \mathrm{MB}$ is the least characterized, and Group 3 has the worst prognosis, and here high doses of cytotoxic chemotherapy are still indispensable, so current studies focus on optimizing the doses of cytostatic drugs to balance efficacy and toxicity rather than utilizing targeted therapies (37). Some potential targets for SHH and WNT MB are discussed below, and in addition, some more general targets are presented.

The hedgehog pathway. SHH MB is characterized by a constitutive active $\mathrm{HH}$ signaling pathway (37). In intact cells, no $\mathrm{HH}$ ligands are present, so PTCH1 inhibits SMO, and thereby inhibits $\mathrm{HH}$ signaling. Extracellular $\mathrm{HH}$ proteins induce the unbinding of PTCH1 and SMO, resulting in activation of the $\mathrm{HH}$ signaling pathway (37). More specifically, SMO translocates into the primary cilium, where it activates the GLI family zinc finger transcription factors (GLI1 and GLI2), which in turn initiate the expression of $\mathrm{HH}$ target genes $(G L I, P T C H 1$, cyclin D1, snail family transcriptional repressor $(S N A I L))$. Mutations in these target genes may lead to SHH MB (39). Therefore, small molecules targeting upstream factors involved in $\mathrm{HH}$ signaling are being investigated as potential treatment.

Vismodegib (GDC-0449) is a Food and Drug Administration (FDA)-approved SMO inhibitor for SHH- dependent cancer but it is not approved for treatment of MB (40). Vismodegib has been shown to be very efficient in tumor suppression in mouse models, and its application induced tumor regression in patients with refractory metastatic MB (19, 40, 41). There are several ongoing clinical trials testing the effect of adjuvant chemotherapy in combination with vismodegib (e.g. NCT01878617). However, mutations in the SMO gene can lead to resistance to SMO inhibitors due to impaired drug binding, and induce disease progression (42). In addition, it was observed that patients with high-risk $\mathrm{SHH} \mathrm{MB}$, with an SUFU mutation, or $M Y C N$ and GLI2 amplifications, did not respond to vismodegib but still developed growth-plate fusions after its application $(17,43)$. Notably, an alternative clinical trial (NCT01601184) in which patients with SHH MB were treated with vismodegib in combination with the alkylating agent temozolomide was stopped, since no positive effect was reached after the first stage of phase II.

To overcome the limitation of acquired resistance to SMO inhibitors, there is an emerging need to find new therapeutic strategies in which molecules downstream of the $\mathrm{HH}$ pathway are targeted. One approach is to epigenetically or directly inhibit the transcription factor GLI, which is considered to be much more efficient than inhibition of SMO, since GLI is a terminal effector of $\mathrm{HH}$ signaling and initiates the transcription of $\mathrm{HH}$ target genes (44). For instance, the GLI antagonists GANT58 and GANT61 bind to the groove between the zinc finger-2 and -3 of GLI without direct interference with DNA (44). Epigenetically, acetylation of a lysine residue on the $C$-terminal end of GLI functions as an inhibitory switch and thereby prevents the expression of $\mathrm{HH}$ target genes (45). An ongoing study (NCT03904862), in which GLI is blocked by a casein kinase 2 inhibitor (silmitasertib), is currently being evaluated in phase I/II trial for patients with recurrent or CDK4/6 pathway relapsed SHH MB (10).

PI3K pathway. Alterations of the signaling pathway of the intracellular lipid kinase PI3K are known to play a crucial role in $\mathrm{MB}$, as well as in other solid tumors, by regulating cellular growth, proliferation and cell survival (46). Activated by growth receptor tyrosine kinases, PI3K recruits and activates protein kinase $\mathrm{B}$, leading to downstream activation of other kinases, e.g. the mammalian target of rapamycin (mTOR), which promotes tumor growth intravasation and invasion, making the inhibition of this pathway favorable for tumor therapy (47). Since PI3K is involved in modulating the survival of MB stem cells following irradiation, agents targeting PI3K and its downstream signaling are considered to be beneficial alone, or in combination with adjuvant chemotherapy (48).

Recently, it was shown that PI3K inhibitors such as alpelisib (BYL719) alone, and in combination with cytostatic 
drugs (cisplatin, vincristine or doxorubicin) reduced viability and proliferation in childhood neuroblastoma cell lines, indicating that these combinations might also be used for MB (49). Targeting not only PI3K, but simultaneously the fibroblast growth factor receptor (FGFR) showed an increased sensitivity compared to single-drug treatment, especially of more resistant MB childhood cell lines, and reduced cell viability and proliferation (46). The combinational inhibition of PI3K (BYL719) and mTOR (OSI-027) even enhanced anti-MB effects in vitro and in vivo compared to single-drug use (50). Thereby, the transcription factor GLI involved in $\mathrm{HH}$ signaling was identified as a target for simultaneous PI3K and mTOR inhibition (50).

Another therapeutic strategy combined targeting of the $\mathrm{PI} 3 \mathrm{~K} / \mathrm{mTOR}$ pathway and HH signaling. Treatment of MB cells with the HH inhibitor vismodegib and the PI3K inhibitor BEZ235 significantly suppressed cell growth and survival, and in addition, increased cisplatin-mediated cytotoxicity (51). In addition, in vivo experiments with $M Y C$ amplified NOD scid gamma mouse models supported this observation, since combinational treatment with vismodegib and BEZ235, or their respective combination with cisplatin delayed tumor growth and enhanced survival of mice (51). Two ongoing clinical trials are currently investigating the use of the PI3K inhibitor samotolisib (LY3023414) in patients with recurrent MB (NCT03213678, NCT03155620) but both are still in the recruitment phase.

The CDK inhibitor pathway. The cyclin D-CDK-inhibitor of CDK4 (INK4) retinoblastoma $(\mathrm{Rb})$ pathway regulates cellcycle progression by initiation of the $\mathrm{G}_{1}-\mathrm{S}$-phase transition. Active CDK4/6 can phosphorylate the Rb tumor-suppressor protein, so it dissociates from E2F transcription factors and thereby allows for DNA replication and cell-cycle progression (52). Increased CDK4/6 activity can be mediated by overexpression of D-type cyclins, mutations, or amplification of CDK4/6, as shown e.g. in MB, or the loss of cyclin D-CDK4/6 negative regulators, for instance p16 ${ }^{\mathrm{INK} 4 \mathrm{~A}}$, which can subsequently lead to cancer growth $(21,53)$. Selective inhibition of CDK $4 / 6$ potently arrests the cell cycle and thereby presents a favorable target for cancer treatment. A theoretical concern about these inhibitors is that CDKs also have an essential role in normal cells. However, cells with a dysregulated CDK4/6-INK4-Rb pathway response, should be more sensitive than normal cells, and in this way these endogenous inhibitors may spare CDK2 activity and allow normal cells to proliferate (54).

Three selective CDK4/6 inhibitors, namely palbociclib, ribociclib and abemaciclib, have been approved by the FDA for treatment of estrogen receptor-positive metastatic breast cancer (55). The addition of CDK4/6 inhibitors to established treatments of $\mathrm{MB}$ might therefore possibly improve the efficacy and durability of the antitumor response, and may potentially overcome acquired or de-novo treatment resistance. According to a study using patient-derived xenograft mouse models, the CDK4/6-cyclin D-Rb pathway was characterized as a 'druggable' pathway for all non-WNT MB (56). Furthermore, experimental data have shown that pretreatment with biologically achievable doses of palbociclib significantly reduced the surviving fraction of tumor cells in response to radiation and increased the sensitizer enhancement ratio (57). Clinical and experimental studies have also demonstrated enhanced cytotoxicity when combining various cytostatic drugs with palbociclib, ribociclib or abemaciclib for several tumor types, e.g. non-small-cell lung carcinoma, breast, ovarian, gastric, pancreatic cancer and others (55, 58-63). Furthermore, addition of CDK4/6 inhibitors enhanced chemotherapy-induced apoptosis of tumor cells in in vitro and in vivo contexts in preclinical studies (55). Combining CDK4/6 inhibitors and chemotherapy is therefore an attractive therapeutic strategy, especially since these inhibitors are not associated with cumulative toxicity and can therefore be administered for a long time period (63).

A clinical study from the St. Jude Children's Research Hospital, USA, has just started and is investigating the combination of the CDK4/6 inhibitor ribociclib with the cytostatic gemcitabine, or in combination with the small molecule trametinib, or with the $\mathrm{HH}$ antagonist sonidegib, respectively, to treat recurrent or progressive $\mathrm{MB}$ (NCT03434262). Another approach is following the combinational treatment comprising the CDK4/6 inhibitor palbociclib, ribociclib, or abemaciclib, respectively, together with the alkylating agent temozolomide and the cytotoxic alkaloid irinotecan (NCT03709680, and NCT04238819). Two clinical trials investigating the single-drug use of either palbociclib or abemaciclib in patients with recurrent or refractory solid tumors (including $\mathrm{MB}$ ) are also ongoing (NCT03526250, NCT02644460).

Immunotherapy. Another treatment approach for $\mathrm{MB}$ is immunotherapy. In a recent review on immunotherapy and medulloblastoma, the authors concluded that cancer vaccines, oncolytic viral therapy, natural killer cells, and CAR $T$ therapy may all be effective against the innate immunosuppressive properties of $\mathrm{MB}$, and thereby potentially prolong survival (64).

Immunotherapy may be beneficial for a variety of cancer types, however, its application in central nervous system tumors is still challenging due to the lack of immunogenic antigens (65). Nevertheless, the variety of dysregulated pathways in MB potentially increases the re-expression of fetal, developmental antigens, which might be targeted since they are not expressed in normal tissue $(65,66)$. To target such antigens might be an attractive strategy, since it would eliminate cancer cells while sparing important surrounding brain tissue $(65,66)$. 
Another alternative is to use immunotherapy in conjunction with chemotherapy or radiotherapy. Clinical and pre-clinical studies have, for example, shown that simultaneous treatment with vaccination (such as with dendritic cells loaded with brain tumor stem cells or total tumor RNA-loaded autologous lymphocyte transfer) and chemotherapy improved antigen-specific T-cell activity (65, 67). Furthermore, low-dose radiation up-regulated expression of human leukocyte antigen class I and class II in various MB cells by more than $20 \%$, while the high amount of reactive oxygen species generated resulted in increased human epidermal growth factor receptor 2 (HER2) and vascular endothelial growth factor expression, which can both be targeted by antibodies $(64,68)$. The latter observations imply synergistic effects of low-dose radiation and the application of monoclonal antibodies.

Notably, anti-HER2 chimeric antigen receptor T-cell (CAR T) therapy is a successful approach to treating several types of cancer, and the HER2 receptor is also known to be overexpressed in MB. Furthermore, one study has already shown that CAR T-cells were able to clear MB implanted in the posterior fossa in mice without any significant toxicity (64). However, antigenic escape is a prevalent challenge, therefore CAR T-cells should be designed to target multiple tumor antigens. A clinical trial is currently investigating HER2 CAR $\mathrm{T}$ therapy in patients with HER2-positive recurrent central nervous system tumor, including those with MB (NCT03500991).

Another clinical trial currently in phase I and II utilizes a cancer vaccine consisting of RNA-loaded autologous dendritic cells (DCs) which is administered to patients with MB (NCT01326104). In this trial, DCs were matured and activated with specific inflammatory cytokines, and then incubated with amplified tumor messenger RNA, which originated from an individual cDNA library from each patient (69). Finally, the DCs were cultured with T-cells and re-administered together with these T-cells to the respective patient with MB. This procedure is complicated and timeconsuming, since tumor cells from each patient have to be collected $(64,69)$. Unfortunately, several clinical trials testing cancer vaccines in MB have been unsuccessful and were terminated (NCT02332889, NCT01171469, NCT00014573).

Other approaches are also useful, as indicated by a research group showing that $\mathrm{MB}$ cells express the poliovirus receptor CD155 on their surface, which allows a poliovirus to infect and inhibit tumor proliferation (70). This serves as an optimal target for oncolytic viral therapy using poliovirus, and has already demonstrated efficacy in vitro (64). CD155 expression was found to be the highest in WNT MB and Group $3 \mathrm{MB}$, and infection by poliovirus reduced proliferation, resulting in cellular death (70). There are several ongoing clinical studies evaluating cancer vaccines using poliovirus, reovirus, or oncolytic herpes simplex virus (NCT03043391, NCT02444546, NCT03911388).

Finally, programmed death-ligand 1 is a favorable target for checkpoint inhibitors but the complete absence of this ligand in MB has been reported (71). Nevertheless, clinical studies are investigating checkpoint inhibitors against programmed death-ligand 1 in patients with $\mathrm{MB}$ (NCT03173950, NCT02359565) (65).

\section{Summary and Conclusion}

Despite recent advances in cancer genomics, the standard of care for all MB subgroups still generally consists of maximal surgical resection, CSI and adjuvant chemotherapy, leading to numerous severe short- and long-term side-effects. For new therapeutic approaches, major efforts have been made to characterize specific gene mutations or amplifications as possible targets for tailored treatment, with some of them being already investigated in pre-clinical or clinical trials.

Currently, $\mathrm{HH}$ pathway inhibitors, already FDA-approved for treatment of other types of tumors, deliver promising clinical trials for the therapy of SHH-driven MB. Other targets such as PI3K or CDK4/6 are highly interesting for personalized therapies, and their use is already being evaluated in several trials for other cancer types. However, one major obstacle is the development of drug resistance to these pathway inhibitors, which could potentially be overcome by combining inhibitors of different pathways. An alternative possibility would be to combine pathway inhibitors, with chemotherapy, since an enhanced sensitivity of MB cancer cells to chemotherapy was revealed when mediated by inhibitor treatment.

In contrast, specific tumor drivers in Group 3 and Group 4 MB have not been well identified, and fewer specific approaches for these subgroups are available. More information on the nature of these tumors and further trials are important in improving patient survival and quality of life.

A different strategy altogether is to treat $\mathrm{MB}$ by immunotherapy, where the major challenge lies in the identification of new antigens to engineer therapies with simultaneously more than one target. In this way, immunosuppression can be counteracted, and the patient's immunity activated by cancer vaccines, viruses, or T-cell therapy.

Finally, continued effort should be made on the molecular characterization of $\mathrm{MB}$, with the aim of personalizing treatment strategy when defining the initial diagnosis, thereby maximally reducing treatment-related toxicity while retaining and improving overall survival. As pre-clinical research is continuously driving the field forward, with large international trials, the biology of individual treatment responses is being more and more understood. Using this comprehensive knowledge, targeted therapies have the potential to improve overall survival as well as the quality of life of MB survivors. 


\section{Conflicts of Interest}

The Authors declare that they have no conflicts of interest.

\section{Authors' Contributions}

HM: Literature research, article writing; TD: literature research, article writing, edits; ONK: Article idea, outline, article writing, edits, submission.

\section{Acknowledgements}

This research was supported by the Stockholm Cancer Society, the Lindhés Advokatbyrå, the Åke Wiberg Foundation, SLS (Svenska Läkaresällskapet).

\section{References}

1 Orr BA: Pathology, diagnostics, and classification of medulloblastoma. Brain Pathol 30(3): 664-678, 2020. PMID: 32239782. DOI: 10.1111/bpa.12837

2 Louis DN, Ohgaki H, Wiestler OD, Cavenee WK, Burger PC, Jouvet A, Scheithauer BW and Kleihues P: The 2007 WHO classification of tumours of the central nervous system. Acta Neuropathol 114(2): 97-109, 2007. PMID: 17618441. DOI: 10.1007/s00401-007-0243-4

3 Archer TC, Mahoney EL and Pomeroy SL: Medulloblastoma: Molecular classification-based personal therapeutics. Neurotherapeutics 14(2): 265-273, 2017. PMID: 28386677. DOI: $10.1007 / \mathrm{s} 13311-017-0526-\mathrm{y}$

4 Smoll NR and Drummond KJ: The incidence of medulloblastomas and primitive neurectodermal tumours in adults and children. J Clin Neurosci 19(11): 1541-1544, 2012. PMID: 22981874. DOI: 10.1016/j.jocn.2012.04.009

5 Ostrom QT, Gittleman H, Truitt G, Boscia A, Kruchko C and Barnholtz-Sloan JS: CBTRUS statistical report: Primary brain and other central nervous system tumors diagnosed in the United States in 2011-2015. Neuro Oncol 20(suppl_4): iv1-iv86, 2018. PMID: 30445539. DOI: 10.1093/neuonc/noy131

6 Pizer BL and Clifford SC: The potential impact of tumour biology on improved clinical practice for medulloblastoma: Progress towards biologically driven clinical trials. $\mathrm{Br} \mathrm{J}$ Neurosurg 23(4): 364-375, 2009. PMID: 19637007. DOI: $10.1080 / 02688690903121807$

7 Kumar V, Abbas AK andAster JC: Robbins basic pathology ebook. Saint Louis: Elsevier,pp. 885, 2017.

8 Northcott PA, Robinson GW, Kratz CP, Mabbott DJ, Pomeroy SL, Clifford SC, Rutkowski S, Ellison DW, Malkin D, Taylor MD, Gajjar A and Pfister SM: Medulloblastoma. Nat Rev Dis Primers 5(1): 11, 2019. PMID: 30765705. DOI: 10.1038/s41572019-0063-6

9 Quinlan A and Rizzolo D: Understanding medulloblastoma. JAAPA 30(10): 30-36, 2017. PMID: 28953021. DOI: 10.1097/01.JAA.0000524717.71084.50

10 De Braganca KC and Packer RJ: Treatment options for medulloblastoma and CNS Primitive Neuroectodermal Tumor (PNET). Curr Treat Options Neurol 15(5): 593-606, 2013. PMID: 23979905. DOI: 10.1007/s11940-013-0255-4
11 Szalontay L and Khakoo Y: Medulloblastoma: An old diagnosis with new promises. Curr Oncol Rep 22(9): 90, 2020. PMID: 32643099. DOI: 10.1007/s11912-020-00953-4

12 Perreault S, Ramaswamy V, Achrol AS, Chao K, Liu TT, Shih D, Remke M, Schubert S, Bouffet E, Fisher PG, Partap S, Vogel $\mathrm{H}$, Taylor MD, Cho YJ and Yeom KW: MRI surrogates for molecular subgroups of medulloblastoma. AJNR Am J Neuroradiol 35(7): 1263-1269, 2014. PMID: 24831600. DOI: 10.3174/ajnr.A3990

13 Ellison DW, Dalton J, Kocak M, Nicholson SL, Fraga C, Neale G, Kenney AM, Brat DJ, Perry A, Yong WH, Taylor RE, Bailey S, Clifford SC and Gilbertson RJ: Medulloblastoma: Clinicopathological correlates of SHH, WNT, and nonSHH/WNT molecular subgroups. Acta Neuropathol 121(3): 381396, 2011. PMID: 21267586. DOI: 10.1007/s00401-011-0800-8

14 Thompson MC, Fuller C, Hogg TL, Dalton J, Finkelstein D, Lau CC, Chintagumpala M, Adesina A, Ashley DM, Kellie SJ, Taylor MD, Curran T, Gajjar A and Gilbertson RJ: Genomics identifies medulloblastoma subgroups that are enriched for specific genetic alterations. J Clin Oncol 24(12): 1924-1931, 2006. PMID: 16567768. DOI: $10.1200 / \mathrm{JCO} .2005 .04 .4974$

15 Northcott PA, Buchhalter I, Morrissy AS, Hovestadt V, Weischenfeldt J, Ehrenberger T, Gröbner S, Segura-Wang M, Zichner T, Rudneva VA, Warnatz HJ, Sidiropoulos N, Phillips AH, Schumacher S, Kleinheinz K, Waszak SM, Erkek S, Jones DTW, Worst BC, Kool M, Zapatka M, Jäger N, Chavez L, Hutter B, Bieg M, Paramasivam N, Heinold M, Gu Z, Ishaque $\mathrm{N}$, Jäger-Schmidt C, Imbusch CD, Jugold A, Hübschmann D, Risch T, Amstislavskiy V, Gonzalez FGR, Weber UD, Wolf S, Robinson GW, Zhou X, Wu G, Finkelstein D, Liu Y, Cavalli FMG, Luu B, Ramaswamy V, Wu X, Koster J, Ryzhova M, Cho YJ, Pomeroy SL, Herold-Mende C, Schuhmann M, Ebinger M, Liau LM, Mora J, McLendon RE, Jabado N, Kumabe T, Chuah E, Ma Y, Moore RA, Mungall AJ, Mungall KL, Thiessen N, Tse K, Wong T, Jones SJM, Witt O, Milde T, Von Deimling A, Capper D, Korshunov A, Yaspo ML, Kriwacki R, Gajjar A, Zhang J, Beroukhim R, Fraenkel E, Korbel JO, Brors B, Schlesner M, Eils R, Marra MA, Pfister SM, Taylor MD and Lichter P: The whole-genome landscape of medulloblastoma subtypes. Nature 547(7663): 311-317, 2017. PMID: 28726821. DOI: 10.1038 /nature 22973

16 Cho YJ, Tsherniak A, Tamayo P, Santagata S, Ligon A, Greulich H, Berhoukim R, Amani V, Goumnerova L, Eberhart CG, Lau CC, Olson JM, Gilbertson RJ, Gajjar A, Delattre O, Kool M, Ligon K, Meyerson M, Mesirov JP and Pomeroy SL: Integrative genomic analysis of medulloblastoma identifies a molecular subgroup that drives poor clinical outcome. J Clin Oncol 29(11): 1424-1430, 2011. PMID: 21098324. DOI: 10.1200/JCO.2010.28.5148

17 Kool M, Jones DT, Jäger N, Northcott PA, Pugh TJ, Hovestadt V, Piro RM, Esparza LA, Markant SL, Remke M, Milde T, Bourdeaut F, Ryzhova M, Sturm D, Pfaff E, Stark S, Hutter S, Seker-Cin H, Johann P, Bender S, Schmidt C, Rausch T, Shih D, Reimand J, Sieber L, Wittmann A, Linke L, Witt H, Weber UD, Zapatka M, König R, Beroukhim R, Bergthold G, van Sluis P, Volckmann R, Koster J, Versteeg R, Schmidt S, Wolf S, Lawerenz C, Bartholomae CC, von Kalle C, Unterberg A, Herold-Mende C, Hofer S, Kulozik AE, von Deimling A, Scheurlen W, Felsberg J, Reifenberger G, Hasselblatt M, Crawford JR, Grant GA, Jabado N, Perry A, Cowdrey C, Croul S, Zadeh G, Korbel JO, Doz F, Delattre O, Bader GD, McCabe 
MG, Collins VP, Kieran MW, Cho YJ, Pomeroy SL, Witt O, Brors B, Taylor MD, Schüller U, Korshunov A, Eils R, Wechsler-Reya RJ, Lichter P, Pfister SM and ICGC PedBrain Tumor Project.: Genome sequencing of SHH medulloblastoma predicts genotype-related response to smoothened inhibition. Cancer Cell 25(3): 393-405, 2014. PMID: 24651015. DOI: 10.1016/j.ccr.2014.02.004

18 Choudhry Z, Rikani AA, Choudhry AM, Tariq S, Zakaria F, Asghar MW, Sarfraz MK, Haider K, Shafiq AA and Mobassarah NJ: Sonic hedgehog signalling pathway: A complex network. Ann Neurosci 21(1): 28-31, 2014. PMID: 25206052. DOI: 10.5214/ans.0972.7531.210109

19 Petrirena GJ, Masliah-Planchon J, Sala Q, Pourroy B, Frappaz D, Tabouret E, Graillon T, Gentet JC, Delattre O, Chinot O and Padovani L: Recurrent extraneural sonic hedgehog medulloblastoma exhibiting sustained response to vismodegib and temozolomide monotherapies and inter-metastatic molecular heterogeneity at progression. Oncotarget 9(11): 10175-10183, 2018. PMID: 29515801. DOI: 10.18632/oncotarget.23699

20 Zhukova N, Ramaswamy V, Remke M, Pfaff E, Shih DJ, Martin DC, Castelo-Branco P, Baskin B, Ray PN, Bouffet E, von Bueren AO, Jones DT, Northcott PA, Kool M, Sturm D, Pugh TJ, Pomeroy SL, Cho YJ, Pietsch T, Gessi M, Rutkowski S, Bognar L, Klekner A, Cho BK, Kim SK, Wang KC, Eberhart CG, Fevre-Montange M, Fouladi M, French PJ, Kros M, Grajkowska WA, Gupta N, Weiss WA, Hauser P, Jabado N, Jouvet A, Jung S, Kumabe T, Lach B, Leonard JR, Rubin JB, Liau LM, Massimi L, Pollack IF, Shin Ra Y, Van Meir EG, Zitterbart K, Schüller U, Hill RM, Lindsey JC, Schwalbe EC, Bailey S, Ellison DW, Hawkins C, Malkin D, Clifford SC, Korshunov A, Pfister S, Taylor MD and Tabori U: Subgroupspecific prognostic implications of TP53 mutation in medulloblastoma. J Clin Oncol 31(23): 2927-2935, 2013. PMID: 23835706. DOI: $10.1200 / J C O .2012 .48 .5052$

21 Northcott PA, Shih DJ, Peacock J, Garzia L, Morrissy AS, Zichner T, Stütz AM, Korshunov A, Reimand J, Schumacher SE, Beroukhim R, Ellison DW, Marshall CR, Lionel AC, Mack S, Dubuc A, Yao Y, Ramaswamy V, Luu B, Rolider A, Cavalli FM, Wang X, Remke M, Wu X, Chiu RY, Chu A, Chuah E, Corbett RD, Hoad GR, Jackman SD, Li Y, Lo A, Mungall KL, Nip KM, Qian JQ, Raymond AG, Thiessen NT, Varhol RJ, Birol I, Moore RA, Mungall AJ, Holt R, Kawauchi D, Roussel MF, Kool M, Jones DT, Witt H, Fernandez-L A, Kenney AM, Wechsler-Reya RJ, Dirks P, Aviv T, Grajkowska WA, Perek-Polnik M, Haberler CC, Delattre O, Reynaud SS, Doz FF, Pernet-Fattet SS, Cho BK, Kim SK, Wang KC, Scheurlen W, Eberhart CG, Fèvre-Montange M, Jouvet A, Pollack IF, Fan X, Muraszko KM, Gillespie GY, Di Rocco C, Massimi L, Michiels EM, Kloosterhof NK, French PJ, Kros JM, Olson JM, Ellenbogen RG, Zitterbart K, Kren L, Thompson RC, Cooper MK, Lach B, McLendon RE, Bigner DD, Fontebasso A, Albrecht S, Jabado N, Lindsey JC, Bailey S, Gupta N, Weiss WA, Bognár L, Klekner A, Van Meter TE, Kumabe T, Tominaga T, Elbabaa SK, Leonard JR, Rubin JB, Liau LM, Van Meir EG, Fouladi M, Nakamura H, Cinalli G, Garami M, Hauser P, Saad AG, Iolascon A, Jung S, Carlotti CG, Vibhakar R, Ra YS, Robinson S, Zollo M, Faria CC, Chan JA, Levy ML, Sorensen PH, Meyerson M, Pomeroy SL, Cho YJ, Bader GD, Tabori U, Hawkins CE, Bouffet E, Scherer SW, Rutka JT, Malkin D, Clifford SC, Jones SJ, Korbel JO, Pfister SM, Marra MA and Taylor MD: Subgroup-specific structural variation across 1,000 medulloblastoma genomes. Nature 488(7409): 49-56, 2012. PMID: 22832581. DOI: 10.1038/nature11327

22 Cavalli FMG, Remke M, Rampasek L, Peacock J, Shih DJH, Luu B, Garzia L, Torchia J, Nor C, Morrissy AS, Agnihotri S, Thompson YY, Kuzan-Fischer CM, Farooq H, Isaev K, Daniels C, Cho BK, Kim SK, Wang KC, Lee JY, Grajkowska WA, Perek-Polnik M, Vasiljevic A, Faure-Conter C, Jouvet A, Giannini C, Nageswara Rao AA, Li KKW, Ng HK, Eberhart CG, Pollack IF, Hamilton RL, Gillespie GY, Olson JM, Leary S, Weiss WA, Lach B, Chambless LB, Thompson RC, Cooper MK, Vibhakar R, Hauser P, van Veelen MC, Kros JM, French PJ, Ra YS, Kumabe T, López-Aguilar E, Zitterbart K, Sterba J, Finocchiaro G, Massimino M, Van Meir EG, Osuka S, Shofuda T, Klekner A, Zollo M, Leonard JR, Rubin JB, Jabado N, Albrecht S, Mora J, Van Meter TE, Jung S, Moore AS, Hallahan AR, Chan JA, Tirapelli DPC, Carlotti CG, Fouladi M, Pimentel J, Faria CC, Saad AG, Massimi L, Liau LM, Wheeler H, Nakamura H, Elbabaa SK, Perezpeña-Diazconti M, Chico Ponce de León F, Robinson S, Zapotocky M, Lassaletta A, Huang A, Hawkins CE, Tabori U, Bouffet E, Bartels U, Dirks PB, Rutka JT, Bader GD, Reimand J, Goldenberg A, Ramaswamy V and Taylor MD: Intertumoral heterogeneity within medulloblastoma subgroups. Cancer Cell 31(6): 737-754.e6, 2017. PMID: 28609654. DOI: 10.1016/j.ccell.2017.05.005

23 Ramaswamy V, Remke M, Bouffet E, Faria CC, Perreault S, Cho YJ, Shih DJ, Luu B, Dubuc AM, Northcott PA, Schüller U, Gururangan S, McLendon R, Bigner D, Fouladi M, Ligon KL, Pomeroy SL, Dunn S, Triscott J, Jabado N, Fontebasso A, Jones DT, Kool M, Karajannis MA, Gardner SL, Zagzag D, Nunes S, Pimentel J, Mora J, Lipp E, Walter AW, Ryzhova M, Zheludkova O, Kumirova E, Alshami J, Croul SE, Rutka JT, Hawkins C, Tabori U, Codispoti KE, Packer RJ, Pfister SM, Korshunov A and Taylor MD: Recurrence patterns across medulloblastoma subgroups: An integrated clinical and molecular analysis. Lancet Oncol 14(12): 1200-1207, 2013. PMID: 24140199. DOI: 10.1016/S1470-2045(13)70449-2

24 Shih DJ, Northcott PA, Remke M, Korshunov A, Ramaswamy V, Kool M, Luu B, Yao Y, Wang X, Dubuc AM, Garzia L, Peacock J, Mack SC, Wu X, Rolider A, Morrissy AS, Cavalli FM, Jones DT, Zitterbart K, Faria CC, Schüller U, Kren L, Kumabe T, Tominaga T, Shin Ra Y, Garami M, Hauser P, Chan JA, Robinson S, Bognár L, Klekner A, Saad AG, Liau LM, Albrecht S, Fontebasso A, Cinalli G, De Antonellis P, Zollo M, Cooper MK, Thompson RC, Bailey S, Lindsey JC, Di Rocco C, Massimi L, Michiels EM, Scherer SW, Phillips JJ, Gupta N, Fan X, Muraszko KM, Vibhakar R, Eberhart CG, Fouladi M, Lach B, Jung S, Wechsler-Reya RJ, Fèvre-Montange M, Jouvet A, Jabado N, Pollack IF, Weiss WA, Lee JY, Cho BK, Kim SK, Wang KC, Leonard JR, Rubin JB, de Torres C, Lavarino C, Mora J, Cho YJ, Tabori U, Olson JM, Gajjar A, Packer RJ, Rutkowski S, Pomeroy SL, French PJ, Kloosterhof NK, Kros JM, Van Meir EG, Clifford SC, Bourdeaut F, Delattre O, Doz FF, Hawkins CE, Malkin D, Grajkowska WA, Perek-Polnik M, Bouffet E, Rutka JT, Pfister SM and Taylor MD: Cytogenetic prognostication within medulloblastoma subgroups. J Clin Oncol 32(9): 886-896, 2014. PMID: 24493713. DOI: 10.1200/JCO.2013.50.9539

25 Ramaswamy V, Remke M, Bouffet E, Bailey S, Clifford SC, Doz F, Kool M, Dufour C, Vassal G, Milde T, Witt O, von Hoff K, Pietsch T, Northcott PA, Gajjar A, Robinson GW, Padovani L, André N, Massimino M, Pizer B, Packer R, Rutkowski S, 
Pfister SM, Taylor MD and Pomeroy SL: Risk stratification of childhood medulloblastoma in the molecular era: The current consensus. Acta Neuropathol 131(6): 821-831, 2016. PMID: 27040285. DOI: $10.1007 / \mathrm{s} 00401-016-1569-6$

26 Moxon-Emre I, Bouffet E, Taylor MD, Laperriere N, Scantlebury N, Law N, Spiegler BJ, Malkin D, Janzen L and Mabbott D: Impact of craniospinal dose, boost volume, and neurologic complications on intellectual outcome in patients with medulloblastoma. J Clin Oncol 32(17): 1760-1768, 2014. PMID: 24516024. DOI: 10.1200/JCO.2013.52.3290

27 King AA, Seidel K, Di C, Leisenring WM, Perkins SM, Krull KR, Sklar CA, Green DM, Armstrong GT, Zeltzer LK, Wells E, Stovall M, Ullrich NJ, Oeffinger KC, Robison LL and Packer RJ: Long-term neurologic health and psychosocial function of adult survivors of childhood medulloblastoma/PNET: A report from the Childhood Cancer Survivor Study. Neuro Oncol 19(5): 689-698, 2017. PMID: 28039368. DOI: 10.1093/neuonc/now242

28 Bull KS, Kennedy CR, Bailey S, Ellison DW and Clifford SC: Improved health-related quality of life outcomes associated with SHH subgroup medulloblastoma in SIOP-UKCCSG PNET3 trial survivors. Acta Neuropathol 128(1): 151-153, 2014. PMID: 24879579. DOI: 10.1007/s00401-014-1300-4

29 Jabarkheel R, Amayiri N, Yecies D, Huang Y, Toescu S, Nobre L, Mabbott DJ, Sudhakar SV, Malik P, Laughlin S, Swaidan M, Al Hussaini M, Musharbash A, Chacko G, Mathew LG, Fisher PG, Hargrave D, Bartels U, Tabori U, Pfister SM, Aquilina K, Taylor MD, Grant GA, Bouffet E, Mankad K, Yeom KW and Ramaswamy V: Molecular correlates of cerebellar mutism syndrome in medulloblastoma. Neuro Oncol 22(2): 290-297, 2020. PMID: 31504816. DOI: 10.1093/neuonc/noz158

30 Schmahmann JD: Neuroanatomy of pediatric postoperative cerebellar cognitive affective syndrome and mutism. Neurology 93(16): 693-694, 2019. PMID: 31527286. DOI: 10.1212/ WNL.0000000000008311

31 Merchant TE, Kun LE, Krasin MJ, Wallace D, Chintagumpala MM, Woo SY, Ashley DM, Sexton M, Kellie SJ, Ahern V and Gajjar A: Multi-institution prospective trial of reduced-dose craniospinal irradiation (23.4 Gy) followed by conformal posterior fossa (36 Gy) and primary site irradiation (55.8 Gy) and doseintensive chemotherapy for average-risk medulloblastoma. Int J Radiat Oncol Biol Phys 70(3): 782-787, 2008. PMID: 17892918. DOI: $10.1016 /$ j.ijrobp.2007.07.2342

32 Hwang EI, Kool M, Burger PC, Capper D, Chavez L, Brabetz S, Williams-Hughes C, Billups C, Heier L, Jaju A, Michalski J, Li Y, Leary S, Zhou T, von Deimling A, Jones DTW, Fouladi M, Pollack IF, Gajjar A, Packer RJ, Pfister SM and Olson JM: Extensive molecular and clinical heterogeneity in patients with histologically diagnosed CNS-PNET treated as a single entity: A report from the children's oncology group randomized ACNS0332 trial. J Clin Oncol : JCO2017764720, 2018. PMID: 30332335. DOI: 10.1200/JCO.2017.76.4720

33 Thariat J, Hannoun-Levi JM, Sun Myint A, Vuong T and Gérard JP: Past, present, and future of radiotherapy for the benefit of patients. Nat Rev Clin Oncol 10(1): 52-60, 2013. PMID: 23183635. DOI: 10.1038/nrclinonc.2012.203

34 Kralik SF, Ho CY, Finke W, Buchsbaum JC, Haskins CP and Shih CS: Radiation necrosis in pediatric patients with brain tumors treated with proton radiotherapy. AJNR Am J Neuroradiol 36(8): 1572-1578, 2015. PMID: 26138138. DOI: 10.3174/ajnr.A4333
35 Packer RJ, Gajjar A, Vezina G, Rorke-Adams L, Burger PC, Robertson PL, Bayer L, LaFond D, Donahue BR, Marymont MH, Muraszko K, Langston J and Sposto R: Phase III study of craniospinal radiation therapy followed by adjuvant chemotherapy for newly diagnosed average-risk medulloblastoma. J Clin Oncol 24(25): 4202-4208, 2006. PMID: 16943538. DOI: 10.1200/JCO. 2006.06.4980

36 Haltom AR, Toll SA, Cheng D, Maegawa S, Gopalakrishnan V and Khatua S: Medulloblastoma epigenetics and the path to clinical innovation. J Neurooncol 150(1): 35-46, 2020. PMID: 32816225. DOI: 10.1007/s11060-020-03591-9

37 Liu X, Ding C, Tan W and Zhang A: Medulloblastoma: Molecular understanding, treatment evolution, and new developments. Pharmacol Ther 210: 107516, 2020. PMID: 32105673. DOI: 10.1016/j.pharmthera.2020.107516

38 Thompson EM, Ashley D and Landi D: Current medulloblastoma subgroup specific clinical trials. Trans1 Pediatr 9(2): 157-162, 2020. PMID: 32477916. DOI: 10.21037/tp.2020. 03.03

39 Pak E and Segal RA: Hedgehog signal transduction: Key players, oncogenic drivers, and cancer therapy. Dev Cell 38(4): 333-344, 2016. PMID: 27554855. DOI: 10.1016/j.devcel. 2016.07.026

40 Rudin CM, Hann CL, Laterra J, Yauch RL, Callahan CA, Fu L, Holcomb T, Stinson J, Gould SE, Coleman B, LoRusso PM, Von Hoff DD, de Sauvage FJ and Low JA: Treatment of medulloblastoma with hedgehog pathway inhibitor GDC-0449. N Engl J Med 361(12): 1173-1178, 2009. PMID: 19726761. DOI: 10.1056/NEJMoa0902903

41 Ajeawung NF, Wang HY, Gould P and Kamnasaran D: Advances in molecular targets for the treatment of medulloblastomas. Clin Invest Med 35(5): E246, 2012. PMID: 23043706. DOI: 10.25011/cim.v35i5.18697

42 Sharpe HJ, Pau G, Dijkgraaf GJ, Basset-Seguin N, Modrusan Z, Januario T, Tsui V, Durham AB, Dlugosz AA, Haverty PM, Bourgon R, Tang JY, Sarin KY, Dirix L, Fisher DC, Rudin CM, Sofen H, Migden MR, Yauch RL and de Sauvage FJ: Genomic analysis of smoothened inhibitor resistance in basal cell carcinoma. Cancer Cell 27(3): 327-341, 2015. PMID: 25759019. DOI: $10.1016 /$ j.ccell.2015.02.001

43 Robinson GW, Kaste SC, Chemaitilly W, Bowers DC, Laughton S, Smith A, Gottardo NG, Partap S, Bendel A, Wright KD, Orr BA, Warner WC, Onar-Thomas A and Gajjar A: Irreversible growth plate fusions in children with medulloblastoma treated with a targeted hedgehog pathway inhibitor. Oncotarget 8(41): 6929569302, 2017. PMID: 29050204. DOI: 10.18632/oncotarget.20619

44 Infante P, Alfonsi R, Botta B, Mori M and Di Marcotullio L: Targeting GLI factors to inhibit the Hedgehog pathway. Trends Pharmacol Sci 36(8): 547-558, 2015. PMID: 26072120. DOI: 10.1016/j.tips.2015.05.006

45 Coni S, Antonucci L, D’Amico D, Di Magno L, Infante P, De Smaele E, Giannini G, Di Marcotullio L, Screpanti I, Gulino A and Canettieri G: Gli2 acetylation at lysine 757 regulates hedgehog-dependent transcriptional output by preventing its promoter occupancy. PLoS One 8(6): e65718, 2013. PMID: 23762415. DOI: 10.1371/journal.pone.0065718

46 Holzhauser S, Lukoseviciute M, Andonova T, Ursu RG, Dalianis T, Wickström M and Kostopoulou ON: Targeting Fibroblast Growth Factor Receptor (FGFR) and Phosphoinositide 3-kinase (PI3K) signaling pathways in medulloblastoma cell lines. 
Anticancer Res 40(1): 53-66, 2020. PMID: 31892552. DOI 10.21873/anticanres.13925

47 Yuan TL and Cantley LC: PI3K pathway alterations in cancer: Variations on a theme. Oncogene 27(41): 5497-5510, 2008. PMID: 18794884. DOI: 10.1038/onc.2008.245

48 Hambardzumyan D, Becher OJ, Rosenblum MK, Pandolfi PP, Manova-Todorova $\mathrm{K}$ and Holland EC: PI3K pathway regulates survival of cancer stem cells residing in the perivascular niche following radiation in medulloblastoma in vivo. Genes Dev 22(4): 436-448, 2008. PMID: 18281460. DOI: 10.1101/gad.1627008

49 Holzhauser S, Lukoseviciute M, Papachristofi C, Vasilopoulou C, Herold N, Wickström M, Kostopoulou ON and Dalianis T: Effects of PI3K and FGFR inhibitors alone and in combination, and with/without cytostatics in childhood neuroblastoma cell lines. Int J Oncol 58(2): 211-225, 2021. PMID: 33491755. DOI: 10.3892/ijo.2021.5167

50 Eckerdt F, Clymer J, Bell JB, Beauchamp EM, Blyth GT, Goldman S and Platanias LC: Pharmacological mTOR targeting enhances the antineoplastic effects of selective PI3K $\alpha$ inhibition in medulloblastoma. Sci Rep 9(1): 12822, 2019. PMID: 31492956. DOI: $10.1038 / \mathrm{s} 41598-019-49299-3$

51 Chaturvedi NK, Kling MJ, Coulter DW, McGuire TR, Ray S, Kesherwani V, Joshi SS and Sharp JG: Improved therapy for medulloblastoma: Targeting hedgehog and PI3K-mTOR signaling pathways in combination with chemotherapy. Oncotarget 9(24): 16619-16633, 2018. PMID: 29682173. DOI: 10.18632 /oncotarget. 24618

52 Burkhart DL and Sage J: Cellular mechanisms of tumour suppression by the retinoblastoma gene. Nat Rev Cancer 8(9): 671-682, 2008. PMID: 18650841. DOI: $10.1038 / \mathrm{nrc} 2399$

53 Shapiro GI: Cyclin-dependent kinase pathways as targets for cancer treatment. J Clin Oncol 24(11): 1770-1783, 2006. PMID: 16603719. DOI: $10.1200 / \mathrm{JCO} .2005 .03 .7689$

54 Roberts PJ, Bisi JE, Strum JC, Combest AJ, Darr DB, Usary JE, Zamboni WC, Wong KK, Perou CM and Sharpless NE: Multiple roles of cyclin-dependent kinase 4/6 inhibitors in cancer therapy. J Natl Cancer Inst 104(6): 476-487, 2012. PMID: 22302033. DOI: $10.1093 /$ jnci/djs002

55 Roberts PJ, Kumarasamy V, Witkiewicz AK and Knudsen ES: Chemotherapy and CDK4/6 inhibitors: Unexpected bedfellows. Mol Cancer Ther 19(8): 1575-1588, 2020. PMID: 32546660 DOI: 10.1158/1535-7163.MCT-18-1161

56 Cook Sangar ML, Genovesi LA, Nakamoto MW, Davis MJ, Knobluagh SE, Ji P, Millar A, Wainwright BJ and Olson JM: Inhibition of $\mathrm{CDK} 4 / 6$ by palbociclib significantly extends survival in medulloblastoma patient-derived xenograft mouse models. Clin Cancer Res 23(19): 5802-5813, 2017. PMID: 28637687. DOI: 10.1158/1078-0432.CCR-16-2943

57 Whiteway SL, Harris PS, Venkataraman S, Alimova I, Birks DK, Donson AM, Foreman NK and Vibhakar R: Inhibition of cyclindependent kinase 6 suppresses cell proliferation and enhances radiation sensitivity in medulloblastoma cells. J Neurooncol 111(2): 113-121, 2013. PMID: 23138228. DOI: 10.1007/s11060012-1000-7

58 Gelbert LM, Cai S, Lin X, Sanchez-Martinez C, Del Prado M, Lallena MJ, Torres R, Ajamie RT, Wishart GN, Flack RS, Neubauer BL, Young J, Chan EM, Iversen P, Cronier D, Kreklau $\mathrm{E}$ and de Dios A: Preclinical characterization of the CDK4/6 inhibitor LY2835219: in vivo cell cycle-dependent/independent anti-tumor activities alone/in combination with gemcitabine.
Invest New Drugs 32(5): 825-837, 2014. PMID: 24919854. DOI: $10.1007 / \mathrm{s} 10637-014-0120-7$

59 Vora SR, Juric D, Kim N, Mino-Kenudson M, Huynh T, Costa C, Lockerman EL, Pollack SF, Liu M, Li X, Lehar J, Wiesmann M, Wartmann M, Chen Y, Cao ZA, Pinzon-Ortiz M, Kim S, Schlegel R, Huang A and Engelman JA: CDK 4/6 inhibitors sensitize PIK3CA mutant breast cancer to PI3K inhibitors. Cancer Cell 26(1): 136-149, 2014. PMID: 25002028. DOI: 10.1016/j.ccr.2014.05.020

60 Bonelli MA, Digiacomo G, Fumarola C, Alfieri R, Quaini F, Falco A, Madeddu D, La Monica S, Cretella D, Ravelli A, Ulivi P, Tebaldi M, Calistri D, Delmonte A, Ampollini L, Carbognani P, Tiseo M, Cavazzoni A and Petronini PG: Combined inhibition of CDK4/6 and PI3K/AKT/mTOR pathways induces a synergistic anti-tumor effect in malignant pleural mesothelioma cells. Neoplasia 19(8): 637-648, 2017. PMID: 28704762. DOI: 10.1016/j.neo.2017.05.003

61 Gao Y, Shen J, Choy E, Mankin H, Hornicek F and Duan Z: Inhibition of CDK4 sensitizes multidrug resistant ovarian cancer cells to paclitaxel by increasing apoptosiss. Cell Oncol (Dordr) 40(3): 209-218, 2017. PMID: 28243976. DOI: 10.1007/s13402017-0316- $\mathrm{x}$

62 Dowless M, Lowery CD, Shackleford T, Renschler M, Stephens J, Flack R, Blosser W, Gupta S, Stewart J, Webster Y, Dempsey J, VanWye AB, Ebert P, Iversen P, Olsen JB, Gong X, Buchanan $\mathrm{S}$, Houghton $\mathrm{P}$ and Stancato L: Abemaciclib is active in preclinical models of ewing sarcoma via multipronged regulation of cell cycle, DNA methylation, and interferon pathway signaling. Clin Cancer Res 24(23): 6028-6039, 2018. PMID: 30131386. DOI: 10.1158/1078-0432.CCR-18-1256

63 Iyengar M, O’Hayer P, Cole A, Sebastian T, Yang K, Coffman $\mathrm{L}$ and Buckanovich RJ: CDK4/6 inhibition as maintenance and combination therapy for high grade serous ovarian cancer. Oncotarget 9(21): 15658-15672, 2018. PMID: 29644000. DOI: 10.18632/oncotarget.24585

64 Kabir TF, Kunos CA, Villano JL and Chauhan A: Immunotherapy for medulloblastoma: Current perspectives. Immunotargets Ther 9: 57-77, 2020. PMID: 32368525. DOI: 10.2147/ITT.S198162

65 Sayour EJ and Mitchell DA: Immunotherapy for pediatric brain tumors. Brain Sci 7(10): , 2017. PMID: 29065490. DOI: $10.3390 /$ brainsci7100137

66 Fontebasso AM, Gayden T, Nikbakht H, Neirinck M, PapillonCavanagh S, Majewski $\mathrm{J}$ and Jabado N: Epigenetic dysregulation: A novel pathway of oncogenesis in pediatric brain tumors. Acta Neuropathol 128(5): 615-627, 2014. PMID: 25077668. DOI: 10.1007/s00401-014-1325-8

67 Mitchell DA, Cui X, Schmittling RJ, Sanchez-Perez L, Snyder DJ, Congdon KL, Archer GE, Desjardins A, Friedman AH, Friedman HS, Herndon JE $2^{\text {nd }}$, McLendon RE, Reardon DA, Vredenburgh JJ, Bigner DD and Sampson JH: Monoclonal antibody blockade of IL-2 receptor $\alpha$ during lymphopenia selectively depletes regulatory $\mathrm{T}$ cells in mice and humans. Blood 118(11): 3003-3012, 2011. PMID: 21768296. DOI: 10.1182/blood-2011-02-334565

68 Das A, McDonald D, Lowe S, Bredlau AL, Vanek K, Patel SJ, Cheshier $\mathrm{S}$ and Eskandari R: Immunological low-dose radiation modulates the pediatric medulloblastoma antigens and enhances antibody-dependent cellular cytotoxicity. Childs Nerv Syst 33(3): 429-436, 2017. PMID: 27942918. DOI: 10.1007/s00381016-3305-x 
69 Nair SK, Driscoll T, Boczkowski D, Schmittling R, Reynolds R, Johnson LA, Grant G, Fuchs H, Bigner DD, Sampson JH, Gururangan S and Mitchell DA: Ex vivo generation of dendritic cells from cryopreserved, post-induction chemotherapy, mobilized leukapheresis from pediatric patients with medulloblastoma. J Neurooncol 125(1): 65-74, 2015. PMID: 26311248. DOI: 10.1007/s11060-015-1890-2

70 Thompson EM, Brown M, Dobrikova E, Ramaswamy V, Taylor MD, McLendon R, Sanks J, Chandramohan V, Bigner D and Gromeier M: Poliovirus receptor (CD155) expression in pediatric brain tumors mediates oncolysis of medulloblastoma and pleomorphic xanthoastrocytoma. J Neuropathol Exp Neurol 77(8): 696-702, 2018. PMID: 29878245. DOI: 10.1093/jnen/nly045
71 Vermeulen JF, Van Hecke W, Adriaansen EJM, Jansen MK, Bouma RG, Villacorta Hidalgo J, Fisch P, Broekhuizen R, Spliet WGM, Kool M and Bovenschen N: Prognostic relevance of tumor-infiltrating lymphocytes and immune checkpoints in pediatric medulloblastoma. Oncoimmunology 7(3): e1398877, 2017. PMID: 29399402. DOI: 10.1080/2162402X.2017.1398877

Received February 23, 2021

Revised March 3, 2021

Accepted March 4, 2021 